\author{
Valentina Colcelli, PhD, Researcher of National Research Council \\ IFAC Institute - Via Madonna del Piano, 10 \\ 50019 Sesto Fiorentino, Firenze, Italy \\ valentina.colcelli@cnr.it
}

\title{
OVERVIEW OF THE RELATIONSHIP BETWEEN THE ITALIAN CONSTITUTIONAL COURT AND EU LAW, WITH PARTICULAR REFERENCE TO THE ITALIAN CONSTITUTIONAL COURT'S APPROACH TO RENEWABLE ENERGY POLICY
}

\begin{abstract}
The paper aims to analyse how European Union law and the jurisprudence of the EU Court of Justice currently influence the interpretation of the Italian Constitution and, at the same time, whether there are still limits to the 'internationalisation' and 'Europeanisation' of national constitutional laws that are relevant for the analysis of the Constitution.

Until 2001, there was no mention in the Italian Constitution of the European Union or the interaction between the national and the European legal system.

Following the 2001 reform, a reference to European Union law was introduced in Article 117 of Italian Constitution, and the relationship between the Italian Constitutional Court and EU law changed entirely. For many years, it had been based on the theory of counter-limits (Italian Constitutional Court judgments in Frosini n. 173/1973 and Granital n. 170, 5 June 1984).
\end{abstract}

As an example of the new relationship mentioned above, we use the Italian Constitutional Court's approach to renewable energy policy.

Keywords: Theory of counter-limits, Italian constitutional reform, Monist theories, EU law as a constitutional parameter

\section{INTRODUCTION}

This paper will answer the following questions: 1) does the Italian Constitutional Court refer to EU law when interpreting the Constitution? 2) does the law of the European Union and the jurisprudence of the EU Court of Justice influence constitutional interpretation? and 3) why, in order to reply to these questions, do we use the case of the Italian Constitutional Court's approach to renewable energy policy? The answer to this last question is that one of the first times that EU law 
was used by the Italian Constitutional Court as a parameter was in the interpretation of the division of competence for environmental protection between the central government and the regions.

Before 2001, there was no mention in the judgments of the Italian Constitutional Court to European Union laws or the interaction between the national and the European legal systems.

Following the 2001 reform, a reference to European Union law was introduced into Article 117 of the Italian Constitution, so the relationship between the Italian Constitutional Court and EU law changed entirely.

The chapter is organised as follows. In Section 2 we provide an overview of the historical roots of the approach of the Italian Constitutional Court to Community law. We discuss how the theory of counter-limits formally internalised these historical roots. In the following section (Section 3), we show how the approach mentioned above changed completely after the 2001 constitutional reform. We explain that Article 117 of the Italian Constitution was amended in various ways: on the one hand, EU law and international obligations became limits to the legislative power not only of the state but also of the regions; on the other hand, the division of competences between the national government and the regional governments was reformed. Article 117 explicitly provided the central government with exclusive competence for environmental protection (and, at the same time, entrusted the enhancement of the cultural and environmental heritage to the concurrent power of the state and the regions). Given this new situation, in Section 3 we analyse judgment n. 166/2014, which, like others that preceded it, displays the Italian Constitutional Court's apparent preference for the development of renewable energy over environmental protection, in accordance with EU laws in this area. Section 4 provides an overview of the Italian Constitutional Court's position on EU law as a parameter for the interpretation of the competence for environmental protection between central government and the regions. Our conclusions are in Section 5.

\section{THE ITALIAN CONSTITUTIONAL COURT'S APPROACH TO THE EUROPEAN UNION LEGAL SYSTEM}

The Court of Justice identified the existence of the EU legal system in its judgment in Van Gend en Loos. ${ }^{1}$ Recognising individuals as subjects of the law, and

C-26/62, Van Gend en Loos v Nederlandse Administratie der Belastingen, [1963] ECR, 1. See Vauchez, A., The transnational politics of judicialization. Van Gend en Loos and the making of EU polity, European Law Journal, 2010, No.16, pp. 1-28 
providing remedies (from the Court), was one way to strengthen the Community primauté. The Court used the strategy of declaring that individuals had rights as grounds for its 'constitutional' intuition that a Community legal system existed.

The same was true in the field of fundamental rights: 'For years, the Luxembourg Court has had to rule on fundamental rights cases affecting individuals. ${ }^{2}$ Early in the past it also had to face conflicting cases that concerned the level of protection afforded by national and supranational law.'

At the same time, on the national side, the relationship between the Italian Constitution and the Community legal system was for a long time based on the theory of counter-limits (Italian Constitutional Court judgments in Frosini n. 173/1973 and Granitaln. 170, 5 June 1984), in the same way as in the judgment of the German Constitutional Court of 29 May 1974 in the So Lange case.

The Frontini v Ministero delle Finanze case (Judgment of Italian Constitutional Court n. 183 of 18 December 1973) is the first case in which the Italian Constitutional Court dealt with the problem of the role of the EU Treaties in the Italian legal system.

This judgment developed from the law through which Italy incorporated the institutional Treaty of the European Economic Community (the EEC Treaty) into its legal system (see Article 2 of Law n. 1203 of 14 October 1957). By introducing Article 189 of the EEC Treaty, the Italian parliament had accepted that European regulations have the same value as primary legislation. This Article states that European Regulations have general application, are mandatory in all their parts and are directly applicable in all the Member States.

Thus, the Italian Constitutional Court affirmed that Article 189 of the EEC Treaty did not overstep the sovereignty of the state. As matter of fact, rather than any denial of national freedom or any change in the fundamental constitutional structure of the Italian legal system (neither of which were permitted by Article 11 of the Italian Constitution), by joining the EEC Italy had acquired powers in new international bodies, such as the right to appoint its own representatives to the

2 Since the Stauder case the European Court of Justice has protected the fundamental rights of both individuals and legal persons, as principles of European Community law (Case 29/69, Erich Stauder v City of Ulm, Sozialamt, [1969] ECR, 419)

3 Caballero, S., Court of Justice and national courts: The system of legal protection of EU individual rights, in Colcelli, V., Arnold, R. (eds.), Europeanization through private law instruments, Entwicklungen im Europischen Recht - Developments in European Law - Developpements en droit européen - Herausgegeben von Rainer Arnold, Vol. 6, Regensburg, 2016, p. 21 
European institutions and the right to participate in the European Commission and the European Court of Justice.

In order to declare that European laws are not in conflict with the sovereignty of the state, the Italian Constitutional Court specified that Article 11 of the Italian Constitution only permits limitations on sovereignty in some circumstances. Such limitations could only be to accomplish peace and fairness among the nations. Therefore, such limitations are not acceptable if they would violate the fundamental principles of the Italian constitutional system or the fundamental rights of individuals, or the form of the state as a republic. As matter of fact, Article 139 of the Italian Constitution states that the republican structure of the state cannot be changed even by a constitutional law. Article 139 imposes unequivocal limitations on possible constitutional reforms. In this case, the Court addressed the question of the admissibility of other implicit limits on constitutional reform and whether compliance with these limits can be reviewed by the Constitutional Court itself.

According to the Italian Constitutional Court's interpretation, this was the appropriate justification for Article 189 of the EEC Treaty. Likewise, the Italian Constitutional Court declared that, if there was a different interpretation, only the Court itself has the power to perform a constitutional review of any of the Treaty's rules, because anything else would be contrary to the fundamental principles of the Italian Constitution: 'it is obvious that if even Article 189 had to be given such aberrant interpretation, in such case a guarantee would always be assured that this Court would control the continuing compatibility of the Treaty with the above mentioned fundamental principles'. ${ }^{4}$ Thus Article 11 of the Italian Constitution 'has formed the basis for the Italian court's acceptance of the Community law, although as in the case of the other Member States, this acceptance has not been unconditional'. 5

Anyway, the main point of these judgments relates to the admissibility of constitutional control over Community laws.

Because the law was an expression of the legislative power of a foreign legal system, it was doubtful whether the Italian Constitutional Court in fact had the power to assess whether it was consistent with the Constitution.

The Constitutional Court decided that the law, although it is an expression of the legislative power of another legal system, must be consistent with the fundamental

Frontini v Ministero delle Finanze. For an unofficial translation, see Gaja, G., Unofficial translation of Frontini v Ministero delle Finanze, in CMLR No. 2, 372, 1974, p. 384, p. 384

5 Craig, P., de Búrca G., EU law. Text, cases and materials, Oxford, 2008, p. 363 
principles of the Italian constitutional system. In order to ensure compliance with these fundamental principles, the Court stated that it had the power to review EU laws.

In other words, the main problem for the Italian Constitutional Court was a procedural problem: whether and how the Court can exercise a form of ultra vires review of Community acts ${ }^{6}$ under Article 11 of the Constitution.

At the same time the Court of Justice leapt forward with the above-mentioned debate. In the judgment of the Court of 9 March 1978 in Simmenthal SpA v Amministrazione delle Finanze dello Stato (Case 106/77), the debate centred around three main aspects: whether national law was a defence to a breach of Community law, whether the national court had a duty to give precedence to Community law, and whether a national judge had to wait for conflicting national legislation to be set aside by the Constitutional Court. The answer given by the Court of Justice was that the former Article 189 of the ECC Treaty 'was based on a distinct separation of function between national Courts and ECJ' and 'was based on a clear division of function' (...) 'from determining whether concept of Community law really was applicable to the case before the national court'?

Thus, 'a national court which is called upon, within the limits of its jurisdiction, to apply provisions of Community law is under a duty to give full effect to those provisions, if necessary refusing of its own motion to apply any conflicting provision of national legislation, even if adopted subsequently, and it is not necessary for the court to request or await the prior setting aside of such provisions by legislative or other constitutional means' ${ }^{8}$

The theory of counter-limits was also confirmed in the Granital case (Italian Constitutional Court judgment n. 170, 5 June 1984), ${ }^{9}$ but in this decision the Italian Constitutional Court conformed its judgment to that in the Simmenthal case mentioned above: 'The case is mainly important because the Constitutional Court overruled its jurisprudence. Indeed, since 1984, if Italian laws were in contrast to the European law, they were considered unconstitutional for violation of art. 11 Const. This solution was founded on the idea that, to not reduce the sovereignty

$6 \quad$ Ruggeri Laderchi, P., Report on Italy, in Slaughter, A.-M., Stone Sweet, A., Weiler, J.H.H., (eds.) The European Court and the national courts - Doctrine and jurisprudence, Oxford, 1998, No. 22, ch. 5

7 Craig de Búrca, op. cit. note 5, p. 484

8 C-106/77, Simmenthal SpA v Amministrazione delle Finanze dello Stato, [1978] ECR, 629

9 Spa Granital v Amministrazione delle Finanze, Judgment of Italian Constitutional Court n. 170 of 5 June 1984. For an unofficial translation, see G. Gaja, Constitutional Court (Italy), Decision No. 170 of 8 June 1984, S.p.a. Granital v Amministrazione delle Finanze ;Common Market Law Review, No. 21,1984 , p. 756 
of Parliament, the European law was not directly applicable. Therefore, the application of incompatible European law was possible only in cases of declaration of unconstitutionality of national law.' ${ }^{10}$

Thus, in the Court's opinion, the question of the unconstitutionality of national law on the basis that it is contrary to Article 3(1) of the Treaty was not admissible under Article 11 of the Italian Constitution.

Therefore, in the event of incompatibility between national and European law, the judge is not obliged to appeal to the Constitutional Court, but may decide to apply European law instead of national law. National laws are inapplicable if they conflict with the effects envisaged by EU rules. Disapplication, and an obligation to interpret national law in conformity with Community law, is required from the judiciary of a Member State if the national law does not safeguard the effectiveness of the protection of Community rights. Disapplication, and an obligation to interpret national law in conformity with Community law laid down by the European legal system for the protection of the Community, comes into action. ${ }^{11}$ However, what about the application of EU law by the Italian Constitutional Court?

It is possible to say that, despite the above-mentioned position, the Italian Constitutional Court had never, until the 2001 constitutional reform, used EU law as a constitutional parameter in its constitutional review.

This approach completely changed after the 2001 constitutional reform.

\section{THE ITALIAN CONSTITUTIONAL COURT'S APPROACH TO EUROPEAN LAW AFTER THE 2001 REFORM OF ARTICLE 117 OF THE CONSTITUTION}

Paragraph 1 of the new Article 117 of the Italian Constitution stated for the first time that: 'Legislative powers shall be vested in the State and the Regions in compliance with the Constitution and with the constraints deriving from EU legislation and international obligations.' EU law and international obligations were brought in as a limit to the state's, but also to the regions', legislative power.

10 DicosolaM., Theinteractionbetween EUandnationallawinItaly. Thetheoryof 'limits'and 'counter-limits', in The Interaction between European Law and National Law in the Case Law of Constitutional Courts. Co.Co.A. Comparing Constitutional Adjudication - A Summer School on Comparative Interpretation of European Constitutional Jurisprudence, 2nd Edition, Trieste, 2007, p. 3

11 Colcelli V., Understanding of the built of European Union legal system: The function of individual rights, J. Soc. Sci., 8, 2012, p. 388 
This express reference to EU and international law in the Italian Constitution immediately reminded scholars of monist and dualistic theory in relation to the meaning and interpretation of the new Article 117 of the Italian Constitution.

As a matter of fact, 'with regard to the relationship between international and domestic law, two theories can be proposed: the monist and dualistic theory. On the one hand, the monist thesis, according to which international law and national law of each State must be considered as part of unified system of norms; on the other hand, the dualist thesis according to which domestic law and international law are two independent legal systems. As consequence of this, international norms are not directly applicable in the Italian legal system, where they assume efficacy according to a process of incorporation. (....) The monist theories are characterized by the idea of a structural homogeneity between the international and national level of experiences. The unified scheme in which the various sources of law are subsumed is built up like a pyramid in which each norm draws its foundation from the higher.' ${ }^{\prime 2}$

According to some scholars, Article 117, paragraph 1, simply codified the previous situation without any innovation: it just provided a form of retrospective approbation to European primacy.

However, some other scholars emphasised the prominence that the Constitution gave to European primacy, arguing that Article 117 had paved the way for the acceptance of the Italian monistic thesis.

Such codification centralises the conflict between EU law and the control of national law or, at least, provides a more active role for the national courts, which would retain their role as the principal guardians of the primacy of EU law.

The effective protection of individual rights in the EU legal system derives from the possibility of using those rights in actions before the national courts. ${ }^{13}$

The recourse to remedies goes beyond the approach - which we could define as continental - that makes rules the locus of the importance and effectiveness of individual rights. Thus, individual rights are defined when judges apply rules that conform to and make concrete the objectives pursued by the European Union.

In the EU, individual rights in horizontal and vertical relationships are protected by the national courts.

\footnotetext{
12 Mezzetti L., Polacchini, F., Primacy of supranational law and supremacy of the Constitution. The Italian legal system, in Mezzetti L., et al. (eds.), International Constitutional Law, 2015, pp.141-142

13 C-208/90, Theresa Emmont v Minister for Social Welfare, [1991] ECR, I-4269
} 
It is for 'the legal system of each Member State to determine which court has jurisdiction to hear disputes involving individual rights derived from Community law, but at the same time the Member States are responsible for ensuring that those rights are effectively protected in each case'. ${ }^{14}$

When the national system of protection is not able to guarantee Community rights sufficiently, the 'equipment' provided by the EU legal system comes into action. The EU legal system has established a uniform network of safeguards of rights for Community individuals (liability of the Member State, recovery of sums paid but not due, disapplication and obligation to interpret national law in conformity with Community law) when the judicial system of the Member State does not safeguard the effective protection of Community rights. The EU legal system does not envisage specific or special protection for individual rights. It envisages that the national legal protection provided by the Member States should be effective. $^{15}$

An opportunity to test these theories arises from an analysis of judgment $n$. 166/2014 of the Italian Constitutional Court. This decision follows quite a number of pronouncements by the Italian Constitutional Court on the particular topic of the conflict in competence between the state and the regions regarding the location of renewable energy plants.

Judgment n. 166/2014, like the others that preceded it, addresses the authorisation and certification procedures, including the planning systems, for renewable energy installations, and emphasises two primary aspects:

- The rules on the location of biomass plants form a point of comparison or contrast between energy development and environmental protection in the Italian legal system;

- The prevailing thoughts regarding the Italian Constitutional Court's apparent preference for the development of renewable energy over environmental protection, according to EU laws on this matter.

14 C-179/84, Bozzetti v Invernizzi, [1985] ECR, p. 2317

15 On the origins and scope of the general principle of effective judicial protection in EU law, see Arnull, A., The principle of effective judicial protection in EU law: An unruly horse?, Eu L Rev. 2011, 36, 1, p. 51; Colcelli, V., Il sistema di tutele nell'ordinamento giuridico comunitario e selezione degli interessi rilevanti nei rapporti orizzontali, Europa e Diritto Privato, 2, 2009, pp. 557-585 


\subsection{EU law as a parameter for the interpretation of the competence for environmental protection between central government and the regions.}

In 2001, Article 117 of the Italian Constitution was amended, explicitly providing the central government with exclusive competence in relation to the protection of the environment (and, at the same time, entrusting the enhancement of the cultural and environmental heritage to the concurrent power of the state and the regions). ${ }^{16}$

The production, transport, and distribution of national energy are also concurrent competences of the state and the regions ${ }^{17}$.

'This new structure has provoked many competence conflicts between the State and the Regions, increasing their number and the relevance. The Regions had previously played a substantial role in protecting the environment (mainly in the context of town and land use planning, but also through other matters of regional competence) and the reform of 2001 appears to significantly limit their competence on environmental issues. ${ }^{18}$

The starting point for the analysis of the Italian Constitutional Court's attitude in the field of the location of biofuel plants and the Italian Constitution's approach to environmental protection is the European and national legal framework on renewable energy.

\subsubsection{Juridical framework for renewable energy plants at the EU and national level}

In the framework of the EU's fight against climate change (European Commission, European Climate Change Programme (ECCP) 2000), the EU attempted to accelerate its existing policy approach towards biofuels with a view to reducing its dependency on foreign sources of energy, reducing greenhouse gas (GHG) emissions, and supporting farmers' incomes by providing new outlets for agricultural products.

Directive 2009/28/EC, Directive 2011/92/EU and Directive 2012/27/EU are usually identified as the second generation of EU legislation on renewable energy and biomass plant location. These core Directives relate to the Member States'

\footnotetext{
16 Lugaresi, N., Introduction: Italian environmental law framework, IUCN Academy of Environmental Law e-Journal Issue 2010, No. 1, p. 7

17 Hansen, W., Christopher, M., Verbuecheln, M., EU waste policy and challenges for regional and local authorities, Ecologic - Centre for International and European Environmental Research, Berlin, 2002

18 Lugaresi, op. cit. note 16
} 
obligations to remove non-cost barriers and, in particular, administrative barriers to the increased deployment of renewable energy systems (RES) (Article 13 Directive 2009/28/EC). In fact, the lack of transparent rules and coordination among the competent authorities is recognised as one of the major obstacles to the deployment of RES projects at the national level (Recital 41 of the Preamble to the Directive 2009/28/EC . The EU also adopted Directive 2009/30/EC, which aimed to promote the use of biofuels and other renewable fuels for transport by setting a target of 5.75 per cent for biofuels in the transportation fuel market by 2010. Moreover, in order to support Member States' compliance with this target, the Commission already introduced Directive 2003/96/EC, which allowed the Member States to reduce excise duties to compensate for the higher costs of producing biofuels. ${ }^{19}$

Biomass plants need to comply with the relevant local authority's policies and rules on renewable energy and its transport, and with any policies adopted for a particular location. These policies are different in each Member State. There are also regional arrangements regarding the planning procedures for certification, and educational issues in relation to achieving the targets set in the Directive and at the sub-regional level. Furthermore, biomass plants must also comply with EU Regulation No 1307/2014 and with the sustainability criteria laid down in Article 7b of Directive 98/70/EC and Article 17 of Directive 2009/28/EC.

Communication 2010/C 160/02 does not have a binding character. It is designed to assist the Member States and to facilitate the consistent implementation of the sustainability criteria. However, EU Regulation No 1307/2014 became applicable from 1 October 2015.

For the location of future biomass plants, it will be very relevant to understand whether, and, if so, how, the Member States will in practice implement the sustainability criteria and the Renewable Energy Directive's (Directive 2009/28/EC) counting rules for biofuels in the light of EU Regulation No 1307/2014.

The sustainability principles are the overarching goals that the individual producers should strive to achieve.

In this framework, a very important role is also played by economic operators, because Communication 2010/C 160/02 additionally sets out how economic operators can implement the sustainability criteria and the above-mentioned Renewable Energy Directive. Communication 2010/C 160/02 is accompanied by

19 Colcelli, V., Institutional factors as limitation for biomass circulation in the internal market (Conference paper), UACES 46th Annual Conference, 5-7 September 2016 
voluntary schemes, default values and Commission guidelines for the calculation of land carbon stocks. These represent valuable tools for economic operators who wish to declare that their products comply with the required sustainability standards, even in the absence of effective enforcement by the various Member States.

The Member States are required to coordinate their regulatory approaches on a series of issues, ranging from the arrangement of planning procedures to certification and educational issues, with the aim of achieving the target set forth in the Renewable Energy Directive.

National rules concerning authorisation and certification procedures, including planning procedures, for renewable energy installations should respect the principles of objectivity, transparency, non-discrimination and proportionality (Article 13, including Recitals 40, 41 and 42 to the Preamble of the RED Directive), and, thus, the European Union legislature has respected the principle of procedural autonomy regarding their establishment. ${ }^{20}$

Thus, national legislation on RES is important, not only from an environmental or social point of view, but also from an economic perspective, in the sense that it is closely related to the acceptability of a project to the local society, and the creation of legal certainty for investors. Institutional and administrative legislation may strongly influence the economic and technical choices. ${ }^{21}$ Authorisations may occur through simplified and accelerated procedures, or they may not be relevant in a particular renewable energy project.

\subsubsection{Renewable Energy Directive (RED) transposed into Italian national legislation}

The Renewable Energy Directive (RED) was transposed into Italian national legislation on 3 March 2011 pursuant to Legislative Decree 28/2011, while Directive 2009/30/EC was transposed on 31 March 2011 pursuant to Government Decree 55/2011. According to Italian legislative practice, any provision contained in these Decrees must be implemented through another specific Decree. All the provisions referring to biofuels (energy from renewable sources for transport, sustainability criteria, etc.) were implemented and became effective on 1 January 2012.

20 Edward, V., A review of the Court of Justice's case law in relation to waste and environmental impact assessment: 1992-2011, J Environmental Law, 2013, 25, 3, pp. 515-530; Engle, E., Environmental protection as an obstacle to free movement of goods: Realist jurisprudence in Articles 28 and 30 of the E.C. Treaty, J.L. \& Com., 27, 2008-2009, p. 113

21 Sonneborn, C. L., Renewable energy and market-based approaches to greenhouse gas reduction opportunity or obstacle, Energy Policy, 2004, No. 32, 1799, p. 1805; Cheyne, I., The definition of waste in EC law, EC Law J Environmental Law, 14, 1, 2002, pp. 61-73 
The Decree set Italy's obligatory share of biofuels in the car fuel mix at 4.0 per cent for 2011; this was due to rise to 4.5 per cent in 2012 and to 5.0 per cent by 2014 in order to reach the 10 per cent target by 2020 .

The Italian framework on RES and plant location provides a system based on both economic incentives and a simplified administrative procedure for the authorisation of a large-scale plant. The procedure is called Autorizzazione Unica (AU).

The AU procedure should be used for biofuel plants with a size equal to or greater than $200 \mathrm{~kW}$.

The AU is the legitimate procedure that must be followed for building and managing a biomass plant in Italy. The AU procedure is managed by the relevant Italian region, and, therefore, applications need to be addressed to the region where the plant will be located. An AU application starts an administrative procedure called the Procedimento Unico, which is realised by means of a Conferenza di Servizi. ${ }^{22}$

In the AU procedure, there could also be a mandatory requirement for compensation for the municipal areas involved. According to the national guidelines, the compensation cannot exceed 3 per cent of the income.

22 The list of the documents and administrative authorisations covered in the Autorizzazione Unica includes:

-Environmental authorisation (Dlgs 18 February 2005 n. 59);

-Landscape authorisation (Article 146 Dlgs 42/2004);

-Environmental assessment (Dlgs 152/2006);

-Authorisation for air quality and atmospheric protection based on regional legislation (Dlgs 152/2006);

-Authorisation for waste (Dlgs 152/2006);

-Declaration of non-impediments for building by the Area Protected Authority (L. 6 December 1991 n. 494);

-Municipal authorisation to build in accordance with urban planning (Dpr. 380/2001);

-Declaration by the local firefighter authority of the rules respecting fire prevention (Article 2 Dpr. 12 January 1998 n. 379);

-Declaration of non-impediment for buildings too close to a military zone;

-Declaration of respect for geological and water flow restrictions (Regio decreto 30 December $1923 \mathrm{n}$.

3267 and Article 61, comma 5, Dlgs 152/2006);

-Declaration of respect for seismic rules (L. 2 February 1974 n. 64);

-Declaration of respect for fly zone security by the ENAC/ENAV Authority (Regio Decreto 30 March 1942 n. 327);

-Authorisation for tree cutting in accordance with the regional cutting service;

-Authorisation for the vocational change of the common local use of a rural area (L. 1766/1927);

-Compliance certificate for noise emissions (L. 447/1995);

-Authorisation by the economic development ministry (Article 95 Dlgs 259/2003);

-Authorisation to use and cross public roads;

-Authorisation for plumbing (Dlgs 152/2006);

-Compliance certificate of non-interference with the country's mineral resources (Article 120 Regio Decreto 1775/1933) 


\subsection{The legal framework on renewable energy in light of the conflict regarding the norms on competence between the Italian state and the regions.}

The core directives relate to the Member States' obligation to remove non-cost barriers and, in particular, administrative obstacles to the increased deployment of renewable energy systems (Article 13 Directive 2009/28/EC).

In fact, the lack of transparent rules and coordination among the competent authorities is recognised as one of the major obstacles to the deployment of renewable energy system projects at the national level (Recital 41 of the Preamble to the Renewable Energy Directive).

EU Regulation No 1307/2014 of 8 December 2014 only defined the criteria and the geographic range of highly biodiverse grasslands for the purposes of Article 17 of Directive 2009/28/EC of the European Parliament and of the Council on the promotion of the use of energy from renewable sources.

The Regulation underlines that the harvesting of raw materials is necessary to preserve the grassland status.

The D.lgs. 29 December 2003, n. 387 applied Directive 2001/77/EC on the promotion of electricity produced from renewable energy sources in the internal electricity market at the national level; thus, the Italian framework on renewable energy systems and plant location provides a system based on economic incentives and a simplified administrative procedure for the authorisation of a massive plant. The procedure is called Autorizzazione Unica (AU). As mentioned above, this means a decision that collects the opinions of the various public administrations involved in the proceedings.

The AU is managed by the relevant Italian region, and, therefore, applications need to be addressed to the region where the plant will be located. An AU application initiates an administrative procedure called the Procedimento Unico, which is realised by means of a Conferenza di Servizi that brings all the relevant public administrations around the same table in order to protect the public interest regarding the location of the plant and renewable energy production.

Under Article 12, paragraph 10 of the national d.lgs. 29 December 2003, n. 387 on the promotion of electricity produced from renewable energy sources, guidelines have to be approved to identify the criteria for the location of plants powered by renewable energy sources. 
However, the text of the Italian Constitution, for historical, social and political reasons (and because of the difficulty in amending it), does not expressly consider the environment as a value to be protected.

The most closely related explicit provision is in Article 9 of the Constitution, pursuant to which the Republic must safeguard the landscape and the historical and artistic heritage of the nation. In any event, the environment has been accorded politically unchallenged protection as the result of an evolving interpretation of Articles 9 and 32 (which protects individual and public health) of the Constitution in the case law of the Constitutional Court.

The new structure of Article 117 of the Italian Constitution "has provoked many competence conflicts between the State and the Regions, increasing their number and the relevance. The Regions had previously played a substantial role in protecting the environment (mainly in the context of town and land use planning, but also through other matters of regional competence) and the reform of 2001 appears to significantly limit their competence on environmental issues. ${ }^{.23}$

\section{THE ITALIAN CONSTITUTIONAL COURT'S POSITION ON EU LAW AS A PARAMETER FOR THE INTERPRETATION OF THE COMPETENCE FOR ENVIRONMENTAL PROTECTION BETWEEN THE CENTRAL GOVERNMENT AND THE REGIONS}

The Court has pointed out that, for the local legislature, the identification of criteria on the plant location powered by renewable energy sources' is forbidden in the absence of guidelines approved according to Article 12, paragraph 10, of the d.lgs. 29 December 2003, n. 387 on the promotion of electricity produced from renewable energy sources in the internal electricity market.

The legislative history of the above-mentioned guidelines will not be addressed in this paper, as it is too vast to explain here. It is sufficient to state that the guidelines only entered into force in 2010, which was two years after the relevant law in the region of Puglia (an Italian region; part of judgment n. 166/2014).

However, in 2009, in judgment n. 282, the Italian Constitutional Court stated that the national rules regarding the promotion of electricity produced from renewable energy sources in the internal electricity market contained the fundamental principles of the Italian legal system for the concurrent competences on the production, transport and distribution of national energy. No local rules can derogate or contradict the national rules in this regard.

23 Lugaresi, op. cit. note 16 
In judgments n.119/2010, n. 44/2011 and 224/2012, the Constitutional Court reinforced the above-mentioned position.

Thus, in the particular case of judgment n. 166/2014, it was said that the region of Puglia cannot depart from the provisions of the national laws for this area of competencies; if this were to occur, the regional law would be in violation of $\mathrm{Ar}$ ticle 117 of the Italian Constitution.

Therefore, the region of Puglia cannot establish a prohibition on building a biomass plant in an agricultural area, because Article 12, paragraph 7 of the d.lgs. n. 387 of 2003 establishes that energy plants from renewable sources - including large-scale plants subject to the AU - can be located in agricultural areas.

The national law, specifically Article 12, paragraph 7 of d.lgs. 387/2003, complies with the Renewable Energy Directive, pursuant to which biofuels cannot be obtained from raw materials grown on land with a high biodiversity value.

As matter of fact, an authorisation for a renewable energy plant will take into account the rules that support the agricultural sector, with particular reference to the production of traditional local foods, and the defence of biodiversity, the cultural heritage, and the rural landscape; however, an authorisation will also take into account the purpose of the EU law, which is to increase the production of energy from renewable sources (judgment n. 275 of 2012).

By contrast, where the law tempers this principle - by considering, among other things, the needs of the agricultural sector - it could be defined as an exception to the main rule. Any exception is to be applied and treated as limited (judgments n. 275 of 2012 and n. 278 of 2010 ).

In other words, the national law, by permitting certain limits to the location of plants in agricultural areas, preserves the 'correct insertion of the plants' in the landscape (Article 12, paragraph 10, of the d.lgs. n. 387 of 2003) and prevents damage from being inflicted on the environment and on agriculture. Nevertheless, the pursuit of the development of agricultural production does not assume the role of a fundamental principle in the matter, since this interest is far from the principal aim of the EU law and the national rules.

The Constitutional Court reaffirmed its criteria that the environment is both a constitutional value and a constitutional subject matter, and it made those criteria stronger and clearer.

In any case, this subject matter differs from the others, because its cross-sectional nature affects other matters. 


\section{CONCLUSION}

The Court is entirely aware that other disputes will arise, because 'there is no way to foresee the extreme multiplicity of environmental and connected issues ${ }^{224}$.

Environmental protection is extremely broad and is subject to the goal of a high level of protection. It should also include the purposes of increasing the production of energy from renewable sources and complying with EU law.

National rules concerning authorisation and certification procedures, including planning systems for renewable energy installations, should respect the principles of objectivity, transparency, non-discrimination and proportionality (see Article 13 and Recitals 40, 41 and 42 to the Preamble of the Renewable Energy Directive) because the European Union legislator has respected the established principle of procedural autonomy.

Thus, national legislation on renewable energy is essential not only from an environmental and social perspective or an economic point of view but also to give an understanding of how the law of the European Union and the jurisprudence of the EU Court of Justice have influenced the interpretation of the Italian Constitution.

The Italian Constitutional Court's opinion is that that provision is linked to the fundamental rights enshrined in Article 11 of Constitution, and presupposes respect for the fundamental rights and principles guaranteed by the Italian Constitution.

The judgment n. 166/2014 was referred to the Italian Constitutional Court by the President of the Council of Ministers under the procedure for a declaration of the unconstitutionality of a law at the regional level. Given the decision of the Constitutional Court (judgment n. 166/2014), we must consider Article 117 of the Constitution a new step in the evolution of the model of interaction between the European and the Italian legal systems.

This was the first time, after 2001, that EU law was used by the Italian Constitutional Court as a parameter for the interpretation of the competence for environmental protection between the central government and the regions. Before 2001 there was no mention in the Italian Constitution or in any judgment of European Union law or the interaction between the national and the European legal system.

$24 \quad$ Ibid. 
In this new context, the Italian Constitutional Court, in a growing number of judgments, has started to use EU laws, and also principles from the EU Court of Justice, to analyse Italian rules in constitutional reviews.

We can consider the Italian Constitutional Court judgment n. 178/2015, and its reference to the Charter of Fundamental Rights of the European Union as an interpretation parameter; this judgment was given when the ordinary tribunals submitted to the Constitutional Court the question of the constitutional legitimacy of some provisions of Law Decree n. 98, July 6, 2011, relating to urgent acts for financial stabilisation.

The ordinary tribunals expressed doubts about the legitimacy of the suspension of collective bargaining and actions by civil servants, which, under the provisions mentioned above and subsequently Article 1, paragraph 255 of the Law of 23 December 2014, n. 190, laying down provisions for the preparation of the annual and multi-annual state budget (the 2015 Stability Law), was extended from 2011 until the end of 2015. This choice was made by the Italian government with the aim of cutting public spending. It was considered possible that the decision violated constitutional rights, such as the right to strike and to be represented by a trade union (Article 39 of the Italian Constitution), that are strongly linked to the possibility of negotiating and concluding collective agreements and implementing collective action.

After analysing the provisions contested by the ordinary tribunals, the Italian Constitutional Court held that the suspension of collective bargaining and the actions of public employees should be considered as being in conflict with the Italian Constitution, as such actions violate not only Article 39 of the Italian Constitution, but also all the provisions of international law that establish a secure connection between the right to union activity and collective bargaining action. One of the provisions of international law explicitly mentioned by the Constitutional Court was Article 28 of the Charter of Fundamental Rights of the European Union, which guarantees the 'right to collective bargaining and action'. The 'right to negotiate and conclude collective agreements' is recognised by Article 28 of the Charter of Fundamental Rights of the European Union, which was proclaimed on 7 December 2000 in Nice. Trade union freedom is protected by Article 39, paragraph 1 of the Italian Constitution, in both its individual and its collective dimension, and finds its fulfilment in negotiating autonomy. Various sources of international law help to define the functional link between a collective right, such as the right to collective bargaining, and trade union freedom; among these is Article 28 of the Charter of Fundamental Rights of the European Union. The 
interpretation of the Italian constitutional source is therefore closely related to the evolution of European Union laws, and its coherence depends on the latter.

Judgment n. 129/2006 of 23 March 2006 is important because in it the Constitutional Court declared that European Directives are interposed rules, which is one of the parameters for assessing the conformity of regional laws with Article 117, paragraph 1 of the Constitution.

In the judicial developments (judgment 102/2008 and order no. 103/2008) regarding the Court of Justice, the Constitutional Court defined itself, for the first time, as a 'Court of a Member State' within the meaning of the former Article 234 of the EC Treaty, which allowed it to present a request for a preliminary ruling on the interpretation of Community law to the Court of Justice of the European Communities. It should be remembered that in its previous jurisprudence, in particular order no. 536/1995, the Italian Constitutional Court had always excluded this possibility in general terms. In 1995, the Constitutional Court, emphasising the nature of its functions and the peculiarities of its task, had refused to raise a preliminary question to the Court of Justice of the European Communities. Some scholars have argued that such a recognition, given by a request for a preliminary ruling, must be limited to main proceedings in which the Constitutional Court is the judge of the matter. In any case, the latest judicial developments (judgment $102 / 2008$ and order no. 03/2008) in the jurisprudence of the Constitutional Court are a partial renewal of the strategy of the Italian Constitutional Court, which can be appreciated by looking at this jurisprudence. It has been stated correctly that the constitutional review of legislation shares specific characteristics with the normal jurisdictional function.

Through the road mentioned above, the Italian Constitutional Court reminds us how each constitutional court is the master of its own processes, and how each has designed its own structure and rules.

\section{REFERENCES}

\section{BOOKS AND ARTICLES}

1. Arnull, A., The principle of effective judicial protection in EU law: An unruly horse?, in Eu L Rev. 2011, 36, 1, p. 51

2. Caballero, S., Court of Justice and national courts: The system of legal protection of EU individual rights, in Colcelli, V., Arnold, R. (eds.), Europeanization through private law instruments, Entwicklungen im Europischen Recht - Developments in European Law - Developpements en droit européen - Herausgegeben von Rainer Arnold, Vol. 6, Regensburg, 2016 
3. Cheyne I., The definition of waste in EC law, in EC Law J Environmental Law, 14, 1, 2002, pp. 61-73

4. Colcelli, V., Understanding of the built of European Union legal system: The function of individual rights, in J. Soc. Sci., 8, 2012, p. 388

5. Colcelli, V., Il sistema di tutele nell'ordinamento giuridico comunitario e selezione degli interessi rilevanti nei rapporti orizzontali, in Europa e Diritto Privato, 2, 2009, pp. 557-585

6. Colcelli, V., Institutional factors as limitation for biomass circulation in the internal market (Conference paper), UACES 46th Annual Conference, 5-7 September 2016 [https://www. uaces.org/documents/papers/1601/colcelli.pdf] Accessed 08.02.2018

7. Craig, P., de Búrca, G., EU law. Text, cases and materials, Oxford, 2008

8. Dicosola, M., The interaction between EU and national law in Italy. The theory of 'limits' and 'counter-limits', in Cede P. \& O. (ed.) The Interaction between European Law and National Law in the Case Law of Constitutional Courts. Co.Co.A. Comparing Constitutional Adjudication - A Summer School on Comparative Interpretation of European Constitutional Jurisprudence, 2nd Edition, Trieste, 2007, p.3 [http://www.jus.unitn.it/cocoa/papers/PAPERS\%202nd\%20PDF/Interaction/Italy-interaction.pdf] Accessed 08.02.2018

9. Edward, V., A review of the Court of Justice's case law in relation to waste and environmental impact assessment: 1992-2011, in J. Environmental Law, 2013, 25, 3, pp. 515-530

10. Engle, E., Environmental protection as an obstacle to free movement of goods: Realist jurisprudence in Articles 28 and 30 of the E.C. Treaty, in J.L. \& Com., 27, 2008-2009, p. 113-135

11. Gaja, G., Unofficial translation of Frontini v Ministero delle Finanze, in CMLR No. 2, 372, 1974, p. 384

12. Hansen, W., Christopher, M., Verbuecheln, M., EU waste policy and challenges for regional and local authorities, Ecologic - Centre for International and European Environmental Research, Berlin, 2002

13. Lugaresi, N., Introduction: Italian environmental law framework, IUCN Academy of Environmental Law e-Journal Issue 2010, 1,

[www.iucnael.org/en/documents/486-italy-lugaresi/file] Accessed 08.02.2018

14. Mezzetti L., Polacchini F., Primacy of supranational law and supremacy of the Constitution. The Italian legal system, in Mezzetti L., et al. (eds.), International Constitutional Law. 2015, pp.141-142

15. Ruggeri Laderchi, P., Report on Italy, in Slaughter, A.M., Stone Sweet, A., Weiler, J.H.H., (eds.) The European Court and the national courts - Doctrine and jurisprudence, Oxford, 1998,22 , ch. 5

16. Sonneborn, C. L., Renewable energy and market-based approaches to greenhouse gas reduction opportunity or obstacle, in Energy Policy, 2004, No. 32, p. 1805

17. Vauchez, A., The transnational politics of judicialization. Van Gend en Loos and the making of EU polity, in European Law Journal, 2010, No.16, pp.1-28 


\section{COURT OF JUSTICE OF EUROPEAN UNION}

1. C-26/62, Van Gend en Loos v Nederlandse Administratie der Belastingen, [1963] ECR, 1

2. C-29/69, Erich Stauder $v$ City of Ulm, Sozialamt, [1969] ECR, 419

3. C-106/77, Simmenthal SpA v Amministrazionme delle Finanze dello Stato, [1978] ECR, 629

4. C-179/84, Bozzetti v Invernizzi, [1985], ECR, 2317

5. C-208/90, Theresa Emmont v Minister for Social Welfare, [1991], ECR, I-4269

\section{EU LAW}

1. Commission Regulation (EU) No 1307/2014 of 8 December 2014 on defining the criteria and geographic ranges of highly biodiverse grassland for the purposes of Article $7 b(3)(c)$ of Directive 98/70/EC of the European Parliament and of the Council relating to the quality of petrol and diesel fuels and Article 17(3)(c) of Directive 2009/28/EC of the European Parliament and of the Council on the promotion of the use of energy from renewable sources GU L 351, 9.12.2014, pp. 3-5

2. Directive 98/70/EC of the European Parliament and of the Council of 13 October 1998 relating to the quality of petrol and diesel fuels and amending Council Directive 93/12/ EEC, GU L 350 del 28.12.1998, pp. 58-68

3. Directive $2003 / 96 / \mathrm{EC}$ of 27 October 2003 restructuring the Community framework for the taxation of energy products and electricity, GU L 283 del 31.10.2003, pp. 51-70

4. Directive 2009/28/EC of the European Parliament and of the Council of 23 April 2009 on the promotion of the use of energy from renewable sources and amending and subsequently repealing Directives 2001/77/EC and 2003/30/EC, OJ L 140, 5.6.2009, pp. 16-62

5. Directive 2009/30/EC of the European Parliament and of the Council of 23 April 2009 amending Directive 98/70/EC as regards the specification of petrol, diesel and gas-oil and introducing a mechanism to monitor and reduce greenhouse gas emissions and amending Council Directive 1999/32/EC as regards the specification of fuel used by inland waterway vessels and repealing Directive 93/12/EEC, GU L 140 del 5.6.2009, pp. 88-113

6. Directive 2011/92/EU of the European Parliament and of the Council of 13 December 2011 on the assessment of the effects of certain public and private projects on the environment. Text with EEA relevance, GU L 26, 28.1.2012, pp. 1-21

7. Directive 2012/27/EU of the European Parliament and of the Council of 25 October 2012 on energy efficiency, amending Directives 2009/125/EC and 2010/30/EU and repealing Directives 2004/8/EC and 2006/32/EC, GU L 315 del 14.11.2012, pp. 1-56

8. European Commission, European Climate Change Programme (ECCP) June 2000 , [https://ec.europa.eu/clima/policies/eccp/first_en\#tab-0-0] Accessed 10 March 2018

9. Communication 2010/C 160/02 from the Commission on the practical implementation of the EU biofuels and bioliquids sustainability scheme, OJ, C 160, 19 June 2010 


\section{LIST OF NATIONAL REGULATIONS, ACTS AND COURT DECISIONS}

1. Fronsini v Ministero delle Finanze, Judgment of Italian Constitutional Court n. 183 of 18 December 1973

2. Spa Granital v Amministrazione delle Finanze, Judgment of Italian Constitutional Court n. 170 of 5 June 1984

3. Regione Lombardia v. Tim Italia S.P.A. E, Vodafone Omnitel, Judgment of Italian Constitutional Court n. n. 129 of 23 March 2006

4. Sardegna Region v Government, Judgment of Italian Constitutional Court n. 102/2008 and ordinance 103/2008

5. Molise Region v Government, Judgment of Italian Constitutional Court n 282/2009 of 2 November 2009

6. Puglia Region v Government, Judgment of Italian Constitutional Court n. 119 of 26 March 2010.

7. Toscana Region and A. $v$ Government, Judgment of Italian Constitutional Court n. 278 of 23 June 2010

8. Campania Region v Government, Judgment of Italian Constitutional Court n. 44 of 7 February 2011

9. Sardegna Region v Government, Judgment of Italian Constitutional Court n. 224 of 8 October 2012

10. Provincia Autonoma di Trento v Government, Judgment of Italian Constitutional Court n. 275 of 2012, of 3 December 2012

11. Puglia Region v Government, Judgment of Italian Constitutional Court n. 166 of 11 June 2014

12. Federazione GILDA-UNAMS $v$ Government, Judgment of Italian Constitutional Court n. 178 of 24 June 2015

13. Legge costituzionale 18 ottobre 2001, n. 3 Modifiche al titolo V della parte seconda della Costituzione, Gazzetta Ufficiale n. 248 del 24 ottobre 2001

14. Legge 16 giugno 1927, n. 1766, Gazzetta Ufficiale 3 ottobre 1927, n. 228

15. Legge 2 Febbraio 1974, n. 64, Provvedimenti per le costruzioni con particolari prescrizioni per le zone sismiche, Gazzetta Ufficiale del 21 marzo 1974, n. 76.

16. Legge 14 ottobre 1957, n. 1203, Gazzetta Ufficiale Serie Generale n.317 del 23-12-1957 Suppl. Ordinario n. 3170

17. Legge 26 ottobre 1995, n. 447 Legge quadro sull'inquinamento acustico Gazzetta Ufficiale Serie Generale n.254 del 30-10-1995 - Suppl. Ordinario n. 125

18. Decreto Legislativo 1 agosto 2003, n. 259 Codice delle comunicazioni elettroniche. (GU Serie Generale n.214 del 15-09-2003 - Suppl. Ordinario n. 150)

19. Decreto Legislativo 29 dicembre 2003, n. 387, Attuazione della direttiva 2001/77/CE relativa alla promozione dell'energia elettrica prodotta da fonti energetiche rinnovabili nel mercato interno dell'elettricità, GU Serie Generale n. 25 del 31-01-2004 - Suppl. Ordinario n. 17 
20. Decreto Legislativo 22 gennaio 2004, n. 42 Codice dei beni culturali e del paesaggio, ai sensi dell'articolo 10 della legge 6 luglio 2002, n. 137, Gazzetta Ufficiale Serie Generale n.45 del 24-02-2004 - Suppl. Ordinario n. 28)

21. Decreto Legislativo 18 febbraio 2005, n. 59, Attuazione integrale della direttiva 96/61/ CE relativa alla prevenzione e riduzione integrate dell'inquinamento, Gazzetta Ufficiale 22 aprile 2005, n. 93

22. Decreto Legislativo 3 aprile 2006, n. 152 Norme in materia ambientale. Gazzetta Ufficiale Serie Generale n.88 del 14-04-2006 - Suppl. Ordinario n. 96

23. Decreto Legislativo 31 marzo 2011, n. 55 Gazzetta Ufficiale, Serie Generale n. 97 del 2804-2011

24. Decreto Legislativo 15 gennaio 2016, n. 7 Disposizioni in materia di abrogazione di reati e introduzione di illeciti con sanzioni pecuniarie civili, a norma dell'articolo 2, comma 3, della legge 28 aprile 2014, n. 67. (GU Serie Generale n.17 del 22-01-2016)

25. Decreto Del Presidente Della Repubblica 6 giugno 2001, n. 380, Testo unico delle disposizioni legislative e regolamentari in materia edilizia, Gazzetta Ufficiale - serie generale - $\mathrm{n}$. 245 del 20 ottobre 2001)

26. Regio Decreto Legislativo 30 dicembre 1923, n. 3267. Riordinamento e riforma della legislazione in materia di boschi e di terreni montani, G.U. 17 maggio 1923, n. 117

27. Regio Decreto 30 marzo 1942, n. 327. Approvazione del testo definitivo del Codice della navigazione. Gazzetta Ufficiale n.93 del 18-4-1942

28. Regio Decreto 11 dicembre 1933, n. 1775, G.U, 8 gennaio, n. 5

29. Legge Regionale 21 ottobre 2008, n. 31, Norme in materia di produzione di energia da fonti rinnovabili e per la riduzione di immissioni inquinanti e in materia ambientale, Bollettino Ufficiale della Regione Puglia n. 167 del 24 Ottobre 2008 